\title{
Host Range of Aphid Transmissible Mosaic Virus Infecting Cowpea
}

\author{
S. Surekha*, S. J. Magar, P. Satyadev and V. Prasanna Krishna \\ College of Agriculture, Latur, VNMKV, Parbhani, Maharashtra, India \\ *Corresponding author
}

\begin{abstract}
A B S T R A C T

\begin{tabular}{|l|}
\hline Ke y w o r d s \\
$\begin{array}{l}\text { Cowpea, Viral disease, } \\
\text { Non persistent, Mosaic, } \\
\text { Host range }\end{array}$ \\
\hline Article Info \\
\hline $\begin{array}{l}\text { Accepted: } \\
\text { 22 May } 2018 \\
\text { Available Online: } \\
\text { 10 June } 2018\end{array}$ \\
\hline
\end{tabular}
\end{abstract}

\section{Introduction}

Cowpea (Vigna unguiculata L. Walp) is one of the World's important dicotyledonous leguminous food crops of millions of people in the developing countries (Summerfield et aI., 1974). Worldwide cowpeas are cultivated in approximate 8 million hectares. The total world production was estimated to be about 3.3 million tonnes of dry grain. Area under cowpea in India was 3.9 million hectares with a production of 2.21 million tonnes with the national productivity of $683 \mathrm{~kg} \mathrm{ha}^{-1}$ (Singh et al., 2012). Major states growing cowpea are Maharashtra, Karnataka, Tamilnadu, Madhya Pradesh, Rajasthan and Andhra Pradesh. In Maharashtra, cowpea occupies an area of 11, 800 ha with an average productivity of $400 \mathrm{~kg}$ ha-1 (Anonymous, 2012). Many factors contribute to very low yields and diseases are the ones responsible for reduction in cowpea yield. Among these viral diseases are major constraints to production and yield (Bashir and Hampton, 1996). More than 20 viruses affect cowpea production Worldwide (Thottappilly and Rossel, 1985). Yield losses of almost 90\% or even total crop failure have been reported (Kaiser and Mossahebi, 1975; Raheja and Leleji, 1974). Considering the economic losses caused by the virus the present investigations were carried out in the glass house during 2015 at college of agriculture, Latur.

\section{Materials and Methods}

For host range studies, plant species belonging to the different families viz.Cucurbitaceae, 
Chenopodiaceae, Compositae, Leguminosae, and Solanaceae were raised from healthy seeds in earthen pots containing steam sterilized soil, sand and compost (2:1:1) mixture and maintained in an insect free glass house. Ten plants of each host species were inoculated with the sap extracted from virus infected vegetable cowpea (cv. Pusa Phalguni) plants by conventional leaf rub method and aphid transmission also done simultaneously.

For sap transmission, Sap extracted from virus infected vegetable cowpea (cv. Pusa Phalguni) plants by crushing symptomatic leaves of Pusa Phalguni cultivar of vegetable cowpea with a mortar and pestle in a chilled $0.05 \mathrm{M}$ potassium phosphate buffer $\left(\mathrm{P}^{\mathrm{H}}\right.$ 7.4) containing $0.02 \mathrm{M}$ 2-mercapto ethanol. Test plants were inoculated by conventional leaf rub method with a cotton swab.

Carborandum (800 mesh) was used as an abrasive. Immediately after virus inoculation, the leaves of test plants were rinsed with tap water. All the leguminous plants were sap inoculated on primary leaves before the emergence of the first trifoliate leaf. All other plants were inoculated on the first leaf or fully expanded leaves. The inoculated plants were kept for observation for 4-6 weeks along with the control plants.

For aphid transmission, the apterous forms of aphids were transferred to clean petridishes for 2 hours fasting. This was followed by an acquisition feeding of 40 to 60 seconds on virus infected detached leaves of source plant. Aphids were allowed to make only brief probes of 40 to 60 seconds duration. Aphids still in probing position at 40 seconds were picked up with camel hair brush and transferred in batches of 25 to healthy test plants for inoculation feeding of four hours. The test plants were kept in muslin cages. Later, aphids were killed by spraying with 0.02 percent imidacloprid (17.8 $\quad$ EC) insecticide and plants were maintained in an insect free glass house for three to four weeks. Observations were recorded for the symptoms on test plants.

The following species were used as test plants in host range studies.

Chenopodiaceae

Chenopodiumamar anticolor

Compositae

Carthamustinctorius L.

Helianthus annus L.

Cucurbitaceae

Cucumis sativus $\mathrm{L}$.

Lagenariasiceraria

Luffaacutangula

Momordicacharantia

Leguminaceae

Arachis hypogea $\mathrm{L}$.

Cajanus cajan (L) Milsp.

Cicer arietinum $\mathrm{L}$.

Cyamopsistetragonaloba (L) Taub.

Dolichos biflorus Lam.

Dolichos lablab L.

Glycine $\max (L)$ Merr.

Pisum sativum L.

Trigonellafoenum-graecum $\mathrm{L}$.

Vigna mungo

Vigna radiata (L) Wilerek.

Vigna unguiculata Var. Gomati

Solanaceae

Capsicum annum

Lycopersicon esculentum

Solanummelongena

$N$. benthamiana $\mathrm{L}$.

N. tabacum L. 
Table.1 Reactions of different hosts against aphid transmissible virus infecting cowpea

\begin{tabular}{|c|c|c|c|c|}
\hline $\begin{array}{l}\text { Sr. } \\
\text { No. }\end{array}$ & Host & $\begin{array}{l}\text { No of plants } \\
\text { inoculated }\end{array}$ & $\begin{array}{l}\text { No o plants } \\
\text { showing } \\
\text { symptoms }\end{array}$ & $\begin{array}{l}\text { Types of } \\
\text { symptoms }\end{array}$ \\
\hline \multirow[t]{2}{*}{ I. } & Chenopodiaceae & & & \\
\hline & 1. Chenopodium amaranticolor & 10 & 9 & CLL \\
\hline \multirow[t]{3}{*}{11.} & Compositae & & & \\
\hline & 1. Carthamus tinctorius $\mathrm{L}$ & 10 & - & - \\
\hline & 2. Helianthus annus $\mathrm{L}$. & 10 & - & - \\
\hline \multirow[t]{5}{*}{ III. } & Cucurbitaceae & & & \\
\hline & 1. Cucumis sativus $\mathrm{L}$. & 10 & - & - \\
\hline & 2. Lagenaria siceraria & 10 & - & - \\
\hline & 3. Luffa acutangula & 10 & - & - \\
\hline & 4. Momordica charantia & 10 & - & - \\
\hline \multirow[t]{13}{*}{ IV. } & Leguminaceae & & & \\
\hline & 1. Arachis hypogea $\mathrm{L}$. & 10 & - & - \\
\hline & 2. Cajanus cajan (L) Milsp. & 10 & - & - \\
\hline & 3. Cicer arietinum $\mathrm{L}$. & 10 & - & - \\
\hline & 4. Cyamopsis tetragonaloba (L) Taub. & 10 & - & - \\
\hline & 5. Dolichos biflorus Lam. & 10 & - & - \\
\hline & 6. Dolichos lablab L. & 10 & - & - \\
\hline & 7. Glycine $\max (L)$ Merr. & 10 & 6 & NLL \\
\hline & 8. Pisum sativum $\mathrm{L}$. & 10 & - & - \\
\hline & 9.Trigonella foenum-graecum $\mathrm{L}$ & 10 & - & - \\
\hline & 10. Vigna mungo & 10 & - & - \\
\hline & 11. Vigna radiata $(\mathrm{L})$ Wilerek. & 10 & - & - \\
\hline & 12. Vigna unguiculata Var. Gomati & 10 & 7 & CLL \\
\hline \multirow[t]{6}{*}{ V. } & Solanaceae & & & \\
\hline & 1. Capsicum annum & 10 & - & - \\
\hline & 2. Lycopersicon esculentum & 10 & - & - \\
\hline & 3. Solanum melongena & 10 & - & - \\
\hline & 4. N. benthamiana $\mathrm{L}$. & 10 & 5 & NLL \\
\hline & 5. N. tabacum L. & 10 & - & - \\
\hline
\end{tabular}

CLL $=$ Chlorotic local lesions

NLL $=$ Necrotic local lesions 
Plate.1 Host range of aphid transmissible virus infecting cowpea

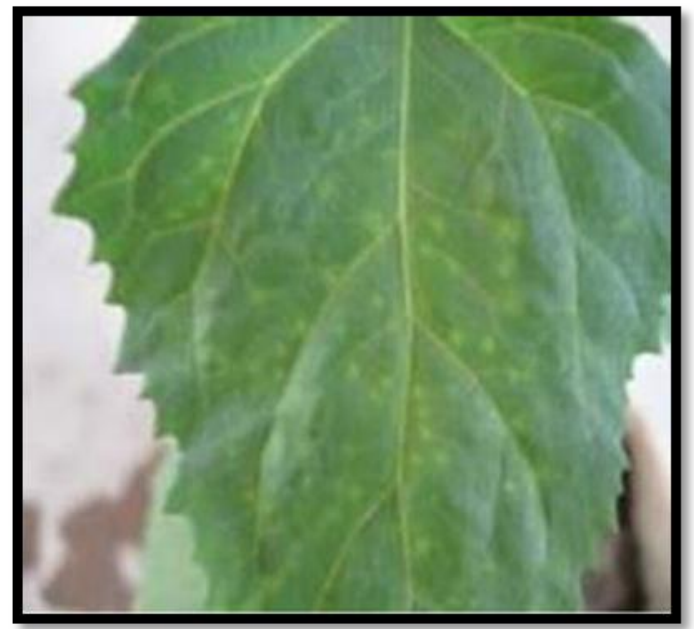

a) Chenopodium amaranticolor showing chlorotic local leisons

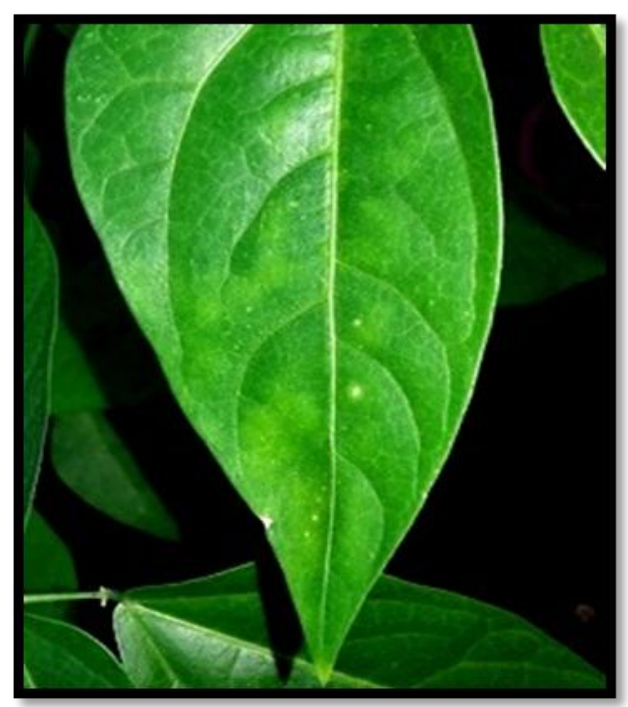

c) Cowpea showing chlorotic local leisons

\section{Results and Discussion}

Symptoms on experimental field and mechanical transmission were characterized by mosaic, veinal necrosis, vein clearing, vein banding, blistering, stunting, leaf

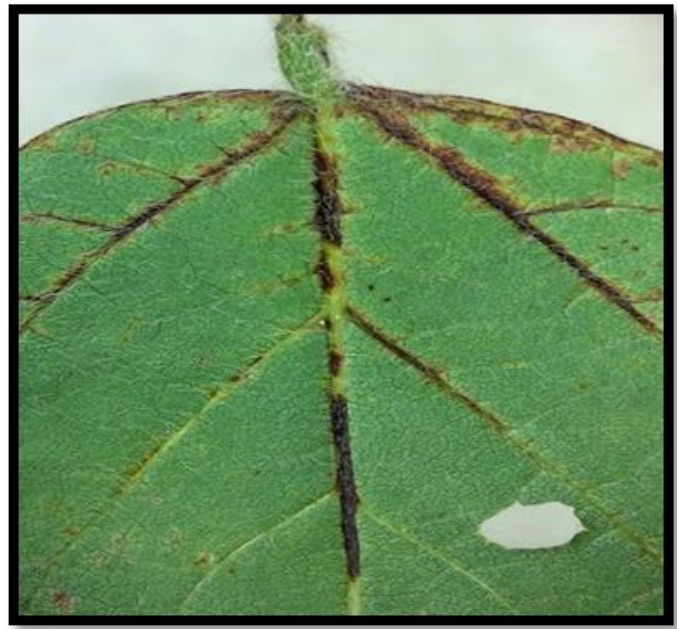

b) Soybean showing necrotic local leisons

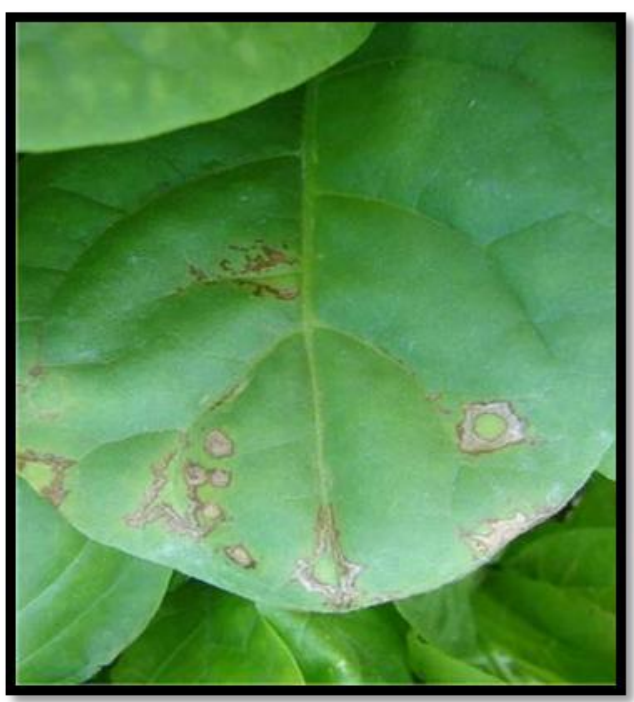

d) Nicotiana benthamia showing necrotic local lesions

deformations, chlorosis and cupping of leaves. Similar result regarding sap transmission was reported earlier by Gahukar and Kalore, (1984); Sekar and Sulochana, (1986); Damiri et al., (2013). 
Reactions of different hosts against aphid transmissible virus infecting cowpea

Results of host range studies (Table 1, PLATE.1) indicated that, aphid transmissible virus of cowpea infected only four plant species and failed to infect 20 plant species. Out of four plant species infected, one from Chenopodiaceae, two from Leguminaceae, one from Solanaceae family, respectively. Out of four host plants Chenopodium amaranticolor, Glycine $\max (L)$ Merr., $N$. benthamiana L. produced only local symptoms. On Vigna unguiculata Var. Gomati, the virus produced both local and systemic symptoms.

The local symptoms produced by Chenopodium amaranticolor and Vigna unguiculata Var. Gomati were chlorotic local lesions whereas the virus produced necrotic local lesions on Glycine $\max (L)$ Merr. and $N$. benthamiana $\mathrm{L}$. The systemic symptoms of vein banding were observed on Vigna unguiculata Var. Gomati. The non-host plants of aphid transmissible virus infecting cowpea were Carthamus tinctorius L., Helianthus annus L., Cucumis sativus L. Lagenaria siceraria, Luffa acutangula, Momordica charantia, Arachis hypogea L., Cajanus cajan (L) Milsp., Cicer arietinum L., Cyamopsis tetragonaloba (L) Taub., Dolichos biflorus Lam., Dolichos lablab L., Pisum sativum L, Trigonella foenum-graecum L., Vigna mungo, Vigna radiata (L) Wilerek., Capsicum annum, Lycopersicon esculentum, Solanum melongena, $N$. tabacum L., respectively. Similar results on host range was reported by Mali and Kulthe (1980a), Sekar and Sulochana (1986), Chiluveru (2003), Damiri et al., (2013), and Santoshi et al., (2015).

Results of host range studies revealed that, aphid transmissible virus of cowpea has restricted host range and infected only four plant species viz., Chenopodium amaranticolor, Glycine max (L.) Merr., Vigna unguiculata Var. Gomati, and Nicotiana benthamiana $\mathrm{L}$. The virus failed to infect 20 plant species.

Based on symptamatology, host range and transmission studies present virus under study was similar to cowpea aphid borne mosaic virus or black eye cowpea mosaic virus. Some workers regarded BICMV and CABMV are closely related or synonymous with each other (Bock and Conti 1974), Taiwo et al., (1982).

\section{References}

Anonymous, (2012). FAO Bulletin of Statistics, Statistics Division of Economics and Social Department. 2: 54.

Bashir, M. and Hampton, R.O. (1996). Detection and identification of seedborne viruses from cowpea (Vigna unguiculata (L.) Walp) germplasm. $\mathrm{Pl}$. Pathol. 45: 54-58.

Bock, K.R. and Conti. M. (1974). Cowpea aphid-borne mosaic virus. CMI/AAB. Description of Plant Viruses No. 134.

Chiluveru, R. (2003). Studies on mosaic disease of cowpea (Vigna unguiculata (L.) Walp.). M.Sc. Thesis (Unpub.) MPKV, Rahuri.

Damiri, B.V., Al-Shahwan, I.M., Al-Saleh, O.A., Abdalla, O.A. and Amer, M.A. (2013). Identification and characterization of Cowpea aphid-borne mosaic isolates in Saudi Arabia. $\mathrm{J}$. Pl. Path. 95(1): 79-85.

Gahukar, K.B. and Kalore, A.R. (1984). Mosaic disease of cowpea in Vidarbha. PKV. Res. J. 8(2): 44-47.

Kaiser, W.J. and Mossahebi, G.H. (1975). Studies with Cowpea aphid-borne mosaic virus and its effect on cowpea in Iran. FAO Pl. Prot. Bull. 23: 33-39. 
Mali, V.R. and Kulthe, K.S. (1980 a). A seedborne potyvirus causingmosaic of cowpea in India. Pl. Dis. 64: 925-928.

Raheja, A.K. and Leleji, O.I. (1974). An aphid-borne mosaic disease of irrigated cowpea in Northern Nigeria. Pl. Dis.58: 1080-1084.

Santoshi, T., Pudake, Mina, D., Koche, Y. N. and Mohod. (2015). Study on host range, physical properties and transmission of cowpea mosaic virus (CPMV). Universe of Emerging Tech. and Sci. 2(4): ISSN: 2349 - 655X, Impact Factor: 0.272.

Sekar, R. and Sulochana, C.B. (1986). Host range of black eye cowpea mosaic virus. Current Sci. India. 55 (23): 1202 1203.

Singh, A.K., Bhatt, B.P., Sundaram, P.K., Santosh, K., Bahrati, R. C., Naresh, C. and Mathura, R. (2012). Study of site specific nutrients management of cowpea seed production and their effect on soil nutrient status. J. Agric. Sci. 4 (10): 191-198.

Summerfield, R.J., Huxley, P.A. and Steele, N.N. (1974). Viruses infecting cowpea (Vigna unguiculata (L.) Walp.)Field Crop Abstr.27: 301-312.

Taiwo, M.A., Gonsalves, D., Provvidenti, R. and Thurston, H.O. (1982). Partial characterization and grouping of isolates of Blackeye cowpea mosaic and Cowpea aphid-bornemosaic viruses. Phytopath. 72: 590-596.

Thottappily, G. and Rossel, H. W. (1985). World-wide occurrence and distribution of virus diseases. In S. R. Singh and K. O. Rachie (Eds.), Cowpea Research, Production and Utilization: 155-171). John Wiley and Sons, Chichester, UK.

\section{How to cite this article:}

Surekha S., S. J. Magar, P. Satyadev and Prasanna Krishna V. 2018. Host Range of Aphid Transmissible Mosaic Virus Infecting Cowpea. Int.J.Curr.Microbiol.App.Sci. 7(06): 30803085. doi: https://doi.org/10.20546/ijcmas.2018.706.362 